TP Periodica Polytechnica

46(1), pp. 29-37, 2015

DOI: 10.3311/PPar.8224

Creative Commons Attribution (1)

RESEARCH ARTICLE

\section{Design Competition for the Fonciére Palace, Andrássy Avenue, Budapest - A Pivotal Moment}

\author{
Márton Székely ${ }^{1 *}$, Katalin Marótzy ${ }^{1 * *}$
}

Received 30 September 2014

\begin{abstract}
The subject of this article is the building history and urban significance of the former 'Fonciére Palace'l at 2 Andrássy Avenue, Budapest. It is a five-storey building facing three streets, built in neo-renaissance style in 1882. It became a listed building in 2013, and is important in the life's work of Adolf Feszty. The stage by stage analysis of the of the design competition is of considerable importance, as the competition was a turning point in the developing architectural culture in early $1880 \mathrm{~s}$ Budapest. Feszty's role in the competitions' history is discussed in this article. Architects' reaction to the building's emphasized urban situation became the competition's key issue. Feszty's solution to this was a monumental cupola on the corner, which was damaged during World War 2 and later pulled down. The absence of the cupola radically decreases the building's architectural values. The present form of the palace is lacking; its effect on the urban landscape is much less impressive.
\end{abstract}

\section{Keywords}

historicism, design competition, urbanism, tenanted property, cupola

\footnotetext{
${ }^{1}$ Department of History of Architecture and of Monuments, Faculty of Architecture, Budapest University of Technology and Economics, H-1111 Budapest, Müegyetem rkp. 3., Hungary

*First corresponding author, e-mail: szekely.marton86@gmail.com

** Second corresponding author, e-mail: mkata@eptort.bme.hu
}

\section{Andrássy Avenue}

Following the Austro-Hungarian Compromise of 1867, Budapest started a period of rapid growth, and by the early 1870 s, the new capital had ambitious plans to rearrange the entire city structure. To prepare for the major urban planning works, the Metropolitan Council of Utility Works was founded. In March 1871, a design competition for general urban rebuilding was announced (Ybl, 1956:p.67). Lajos Lechner's plan 'Veritas', won first prize, with Frigyes Feszl's work 'Metropolis' receiving the second prize (Preisich, 2004:p.169). The most important sections of these plans were the arrangement of the Danube banks, building the 'small' and the 'grand' boulevards, and creating a new elegant promenade leading towards the City Park. The early 19th-century idea of this avenue was again on the agenda. Until the 1870 s, the main route between the city centre and the city park was Király Street. This was neither elegant nor wide enough to meet citizens increasing expectations. The finally realised plan was carried out by widening the older streets and merging smaller sites. The construction of the avenue and the demolition of old buildings started in 1872, but in the following year, the financial crisis (Panic of 1873) caused significant interruption to the works. By 1876, only forty houses had been completed, several of them were the investment of the Avenue Corporation (Preisich, 2004:p.169). From 1880, the building industry started booming again, and all the sites of the avenue were developed within in five years. The avenue is an urban composition divided into three sections. The first section, from Bajcsy Zsilinszky Road (its 19th-century name was Váci Road) to Octagon Square, has the highest density; it is bordered by five-storey buildings and alleyways. The second section is from Octagon to Körönd (Kodály Circus), which is wider and possesses two service roads and four rows of trees along its distance. The last part of the avenue, having the lowest density of buildings, leads into the city park. Initially, there are forecourts in front of the houses, which stand in a row; later, only detached houses, villas. The architectural values of the avenue are indisputable, but the start and the end point were considered

1 Its historical monument registration number is: 15548 . 
urbanistically unsolved. There was an intention to elevate an object, which pointed out the roads axis. Ybl made the first attempt to solve this question with a small gloriette - built in 1883. In reality, it was a monumental flag holder between two curved stairs with balustrade railings. Today it is at Széchenyi Hill, Buda. The gloriette was the well-house of the thermal spring until 1897 (Hajós, 2001:p.10). Vilmos Zsigmondy had the well built in 1878; however, the edifice was not sufficiently emphatic, and was later pulled down. At the turn of the century, the 'Millennium Monument' was built on the site (Heroes' Square), giving a permanent final point for Andrássy Avenue. Albert Schickedanz's architectural composition, with mostly György Zala's statues, was finished in 1906.

The point of origin remained a longer-term problem. The avenue met Bajcsy Zsilinszky Road at an acute angle, practically branching off from that road. The issue of the true beginning of the avenue continued to be debated (VU 1884 no.7:p.109). Bajcsy Zsilinszky Road was already a high density, wide street, with four to five-storey buildings; although, these houses were not at all representative. Consequently, the new Andrássy Avenue connection to the existing city structure was somewhat incidental. The overture to the avenue consisted of two terraced properties. On the northern side the Fonciére Palace, on the southern side the Stein House, designed by Adolf Lang in 1876. They did not solve the structural problems of the connection, but at least created a dignified gateway to the avenue.

The site of the later Fonciére Palace was the most unusually formed site on the avenue. The acute angled corner gave it its uniqueness. The former house standing on this spot also had an acute angled corner although we do not know much about the building. It probably had two or three storeys and was built in classicist style, although not significant. It was torn down in summer 1881. The new parcelling kept this form, so the replacement building would require two main facades meeting at an acute angle. This situation provided the opportunity for inventive architectural experiments. Because of this complicated situation, and the high price, the site remained undeveloped during the first half of the avenue's construction period.

\section{Previous plans to the site}

The Metropolitan Council of Utility Works (FKT from the original) proposed Miklós Ybl and István Linzbauer for the study plans of the most important sites of the new avenue (Ybl, 1956:p.68). Linzbauer was an official architect of the royal and imperial court; he designed the Chateau Nádasdy and the present facade of the Ludovica Academy (originally designed by Mihály Pollack). They also produced the plans for the site of the later Fonciére Palace. Both architects worked on a concept for the site, the plans of which are still available today. From Ybl, the 1872 study plans with floor plans and elevations show a corner-composition, which is similar to Feszty's final solution,
Feszty was probably aware of this study plan. The grand pilaster order on facades during early historicism was rare, this aquarelle drawing shows a facade dominated by sgraffito decoration; its appearance is similar to Gusztav Petsacher's house on the Körönd Circus. Linzbauer's plan included the Opera House on this site. The existing rendering shows the building from the south. Its facade with a curved colonnade had a strong effect on Semper's opera house in Dresden, a photo of this plan can be found in the Szabó Ervin Library, Budapest collection.

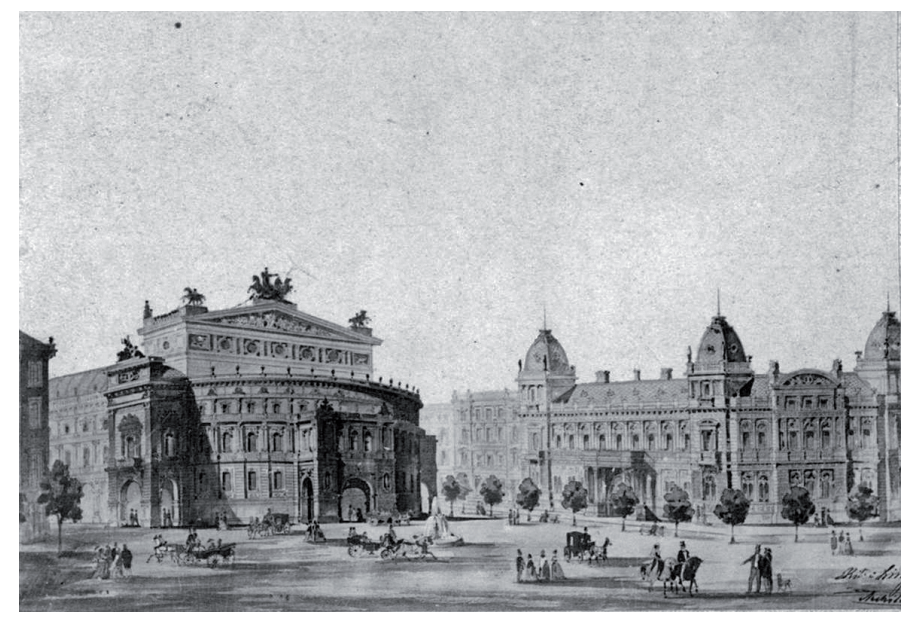

Fig. 1 Rendering of Linzbauer's plan (FSZEK Budapest collection, No. 010165)

We do not see any cupola in either plan as, in reality, in the early 1870s, this element was not often used; it became more popular in the later historicism (Winkler, 1993:p.31). By the time of the Fonciére Palace, it was already a widespread solution for building corner decoration so was an obvious choice for Feszty.

Until the mid-19th century, only sacred or monumental public buildings had cupolas, towers and domes. These elements created a vertical emphasis marking the building's special function, typically with a rotunda below the cupola, although this was missing in this case. The cupola element within buildings' composition ensures and emphasises its significance.

By the second half of the 19th century, the requirements of the growing middle class indicated a need for new urban development methods. The rapidly growing number of new buildings and improved quality resulted in an unprecedented new relationship between the houses of the street. Many sophisticated buildings were elevated in a row and coordinated with one another. The architectural unity was no longer a palace or a church; it was a row of private houses, blocks, corners.

Earlier, an emphasis such as a corner-cupola was not necessary, as such a relationship did not exist between buildings - in a classicist sense there is no dome or tower. However, as the buildings changed, the new elements appeared. These no longer symbolised function; they marked the key points of the urban landscape, which made sense in the landscape situation, not in the building's own order. 
The first corner-cupola of this kind in Budapest was on the building of the 'Pesti Első Hazai Takarékpénztár' (a bank), built in 1868 by Ybl, in Reáltanoda Street. This cupola was octagonal and topped by a lantern. Later, in the mid-1870s, further cupolas appeared on significant corners. A similar cupola was built on the new University Library and the National Theatre's rented building in 1875-76, designed by Anton Skalnitzky. These were built in pure neo-Renaissance style and were more classical despite the later dynamism around the turn of the century. ${ }^{2}$

\section{The life and work of Adolf Feszty ${ }^{3}$}

He was born in 1846, in Ógyalla, a village in present-day Slovakia. His brother was Árpád Feszty, the famous painter. In 1857, he was sent to high school in Bratislava, later attending the Vienna Technical University. From 1866, he studied at the Zürich Technical University, where he became a student of Gottfried Semper. After graduation, he made study trips all around Europe, for example to Great Britain and France, where he visited London and Paris. In 1871, he returned to Budapest and opened an architectural office in Akadémia Street. He soon became popular and received significant proposals from prestigious patrons. His first grandiose work was the 'Haris Bazaar' built in 1878. It was pulled down in 1910 and replaced by sixstorey terraced buildings on both sides; today Haris Close. Not just his architectural but also his engineering talents were demonstrated during this work; he also calculated the method for the load tests of the glass-iron roof (Szénássy, 1993:p.37). From this time on, he was an active architect designer until the mid1880s. He worked on fourteen of the properties ${ }^{4}$ on Andrássy Avenue. The most significant of these was the Fonciére Palace. He designed the new building for the horse race course with its cast iron grandstand roof. It opened in 1885 and was demolished in 1949 to make way for the new national stadium. His later works include the neo-renaissance building of the Bank of Hungary, which was completed in 1885 at 4 Nádor Street; today, it is used by the Ministry of the Home Office. Other works included three simple buildings on the Budapest Grand Boulevard; 48 and 50 Teréz Boulevard and 67 József Boulevard - the latter was significantly rebuilt later. He was elected as an MP in 1887, gradually resigning from architectural activities. In 1890, he gave up planning and spent his time managing a farm, where he experimented with producing paper from peat (Szénássy, 1993:p.71). He died at the age of 54 in 1900.

2 Great masters of these kind of cupolas were later: Alajos Hauszmann, Győző Czigler or the Giergl-Korb couple.

3 The details can be found in in Árpád Szénássy's monography on Feszty. (The life and work of Adolf Feszty, 1993)

4 These are no. $2,8,10,15,17,35,46,55,60,72,78,84,86$ and 96 .

\section{Feszty's role in the introduction of plan competitions in Hungary}

In 1872, during the planning of a new university building, the 26-year-old Feszty proposed a proclamation to the minister for education and culture to introduce the system of open designcompetitions, at least partially, instead of direct requests ${ }^{5}$. In Hungary in the 1870 s, this method was not yet widespread; for the most significant works, they proposed the elder architects directly. It infuriated the younger architects who had broader perspectives and had studied in Western Europe. The proclamation's undoubted progressivity represents Feszty's sensitivity to the public affairs of his profession; later he even became a Member of Parliament. During the long debate, the supporters argued the advantages for the young talented colleagues, ${ }^{6}$ while the opponents, fearing their old positions to be lost, declared they would not take part in such competitions. Ultimately, they were unable to make a clear decision, but the statement was still sent to the minister in charge. Although the protest did not have a direct effect, in the long term it helped to form the competition culture, which reached a more developed level by the beginning of the 20th century. The most important parts of the manifesto included:

“(...) publishing the competition within the country would not only serve to encourage entrants to attempt the design of larger, more monumental building, but the appreciation of the received plans would be much greater than in other countries where (...) the talented have already had the opportunity to order themselves according to their merits and where for exactly the same reason have no interest in risking their already occupied higher status by re-entry into the competition sphere."

"(...) the design competition will, without doubt, stimulate and educate all the Hungarian architects, whose qualification will undoubtedly improve." 7

\section{The building history of the Fonciére Palace}

The 'Pest Insurance Company', founded in 1864, did not succeed in the Hungarian market and joined the Belgian 'Fonciére Company' in 1879. The firm's office was in Sas Street. The company decided to build new luxury residential tenanted houses; the main reason being to advertise the firm's strength and reliability. They chose the first site on the western side of Andrássy Avenue and announced their intention to purchase the lot, which was discussed by the FKT on 27 January 1881 (ÉpIp 1881:p.46). Following the successful purchase and acquisition of the site, the FKT announced on 10 February 1881 that the five-storey building must be completed by 1884 (ÉpIp 1881:p.65) on the plot bordered by Andrássy Avenue,

5 Exceptions were: the Scientific Academy, the Opera House, old chamber of the house of deputies. (Kemény, 1991:p.32; Ybl, 1956:p.76; Pereházy, 2000:p.102) 6 Antal Wéber and Béla Ney supported it. (MMÉEg, 1872:p.172.)

7 Quotation from the minutes of MMÉE seat on 20 april 1872. (MMÉEg) 
Bajcsy Zsilinszky Road and Révai Street, for 250 thousand forints. This counted as a high price at the time; for comparison, the site of the later Opera House cost 500 thousand forints Borsa and Tolnay, 1984). The company announced an open design competition for the plans of a new five-storey building with a deadline of 10 April 1881 (ÉpIp 1881:p.129). Fiftyeight applications were received, eight from Vienna, the rest from Budapest. An article was published in the Bauzeitung für Ungarn, titled: Concurrenz-Pläne für die 'Fonciére' (BFU 1881:p.90). The jury comprised Miklós Ybl, Anton Weber, Ferdinand Fellner and representatives of the insurance company. They awarded four equal prizes of eight hundred forints: Ödön Lechner, Zsigmond Quittner, Adolf Feszty and Gyula Pártos. The plan names were: Zsigmond Quittner - Bramante; Adolf Feszty - Red Star; Ödön Lechner - We are going competitively; Gyula Pártos - Point de Vue (ÉpIp 1881:p.141).

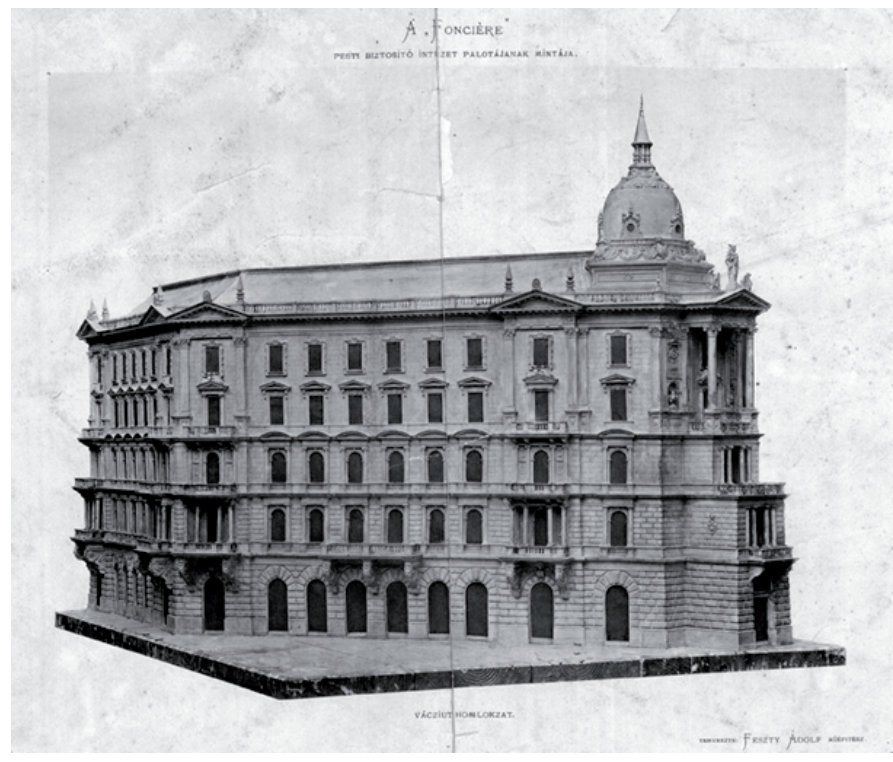

Fig. 2 Plaster model of Feszty's plan (Museum of Hungarian Architecture, No. 2001.1.18.)

Ultimately, Feszty's work Red Star was chosen. Feszty initially made a plaster model ${ }^{8}$ of the building, which received its building license on 19 July 1881. The authority demanded the cupola's plans to be licensed separately. ${ }^{9}$ The significantly modified plans of the cupola were presented later, on 15 May 1882. Construction works started in summer 1881 , by master builder József Pucher. He commenced with the demolition of the former house still standing on the site. Later that year, on 27 September, the builders presented an application to the authorities to extend the avon-corps by twenty centimetres. ${ }^{10}$

8 The original photo of the model is in the collection of the Hungarian Architectural Museum. '2001.01.18.'

9 The authority mentioned the object as 'tower' (Vadas, 2007:p.8)

10 They receieved the license due to urban landscape reasons. (see more detailed: Vadas, 2007:p.9)
They reached the highest point in 10th December and held the usual ceremony. The building gained its residence permit on 28 October 1882. ${ }^{11}$

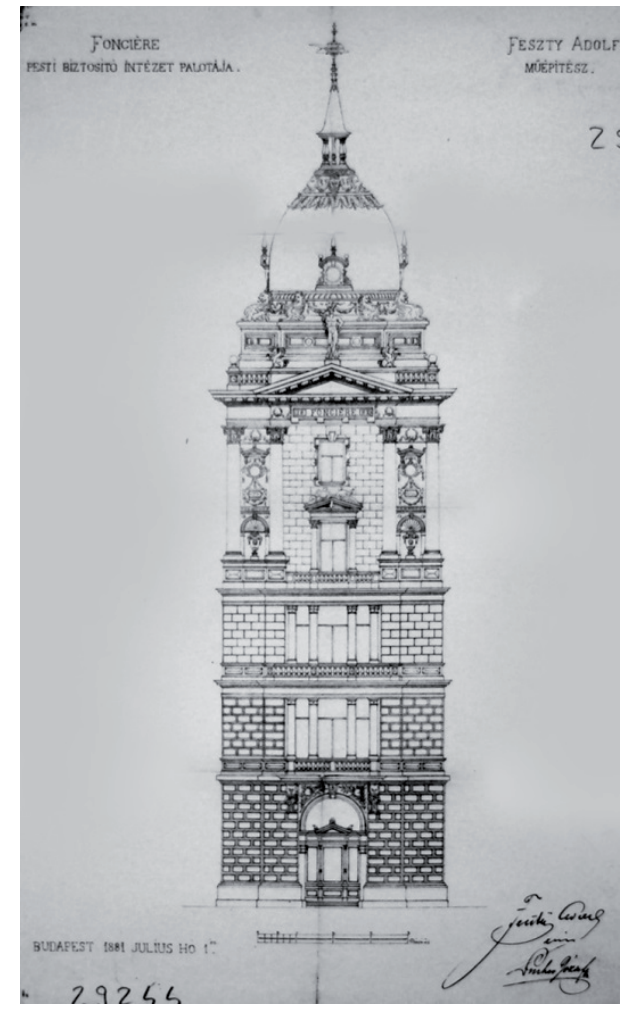

Fig. 3 Corner elevation - first version, 1881 (BFL, HRSZ. 29244)

The contemporary reflections were strong in both the general and the technical press. Almost everyone praised the monumental urban landscape effect of the corner cupola, the representative creation and the fine details. The architectural press emphasised the modern materials, technologies and exemplary quality of the construction works. They noted the tin works of the cupola carried out by Mátyás Zellerin's company, whose metal works reached a level unseen before in Hungary. This is clearly shown in an old photograph by Hermann Rückwardt, which fortunately survived. It was published in"Budapest Architectural Studies', Berlin, 1889. The list of builders was publicised in the 'Bauzeitung für Ungarn' (BFU 1882:p.221). Several of them were famous experts and had worked on many other constructions. For example, Luigi Depold mosaic maker, Mátyás Zellerin, Robert Scholtz, Guilbrand Gregersen, Vilmos Marchenke and József Pucher. In 1883, Feszty made slight alterations to the building, but these were just rearrangements of some flat-layouts (Vadas, 2007:p.10). No notable alterations occurred later except the construction and alteration of the portals. A restoration was carried out around 1900, with all the facades scaffolded. During the Second World War siege of Budapest, the cupola was damaged but survived. Instead of restoration, it was demolished in

11 BFL IV. 1407/b. III. 614/1882. 1vt. sz., 49416/882. tan. sz. 
September $1945 .{ }^{12}$ Fortunately, the rest of the exterior decoration of the palace and sculpture remained unharmed. In 1979, there was a general exterior restoration (Vadas, 2007:p.6). The staircase and the entrance hall, designed by Géza Máthé (Déry, 2006:p.143), were refurbished in 1982. During the last facade renovation in 2008 , the original sign with the original lettering was restored on the portico of the corner facade: 'Fonciére Insurance Company of Pest'. Today's sign is the exact copy of the original, restored with the help of an old photo. The original had disappeared by the 1930s.

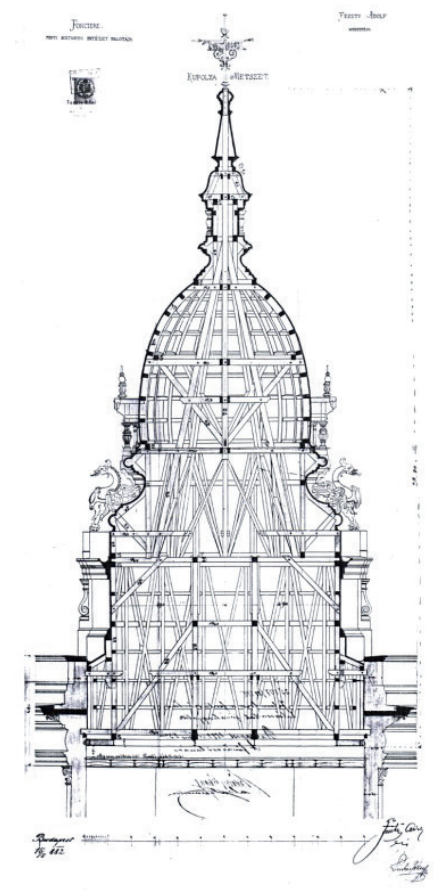

Fig. 4 Section of the cupola, 1882 (BFL, HRSZ. 29244)

\section{The Palace}

\subsection{General description}

The tenanted property of the Fonciére Insurance Company stands at 2 Andrássy Avenue. It is a five-storey building facing to three streets. The palace has twelve axes to Andrássy Avenue, nine to Bajcsy Zsilinszky Road and seven to Révay Street. In the acute angle of the two main roads, a small single axis facade was created by cutting the vertex of the site. Its plane is perpendicular to the bisectors of the two main roads' axes. The Révai Street elevation is virtually parallel to Andrássy Avenue. The nearly square shaped inner courtyard is surrounded by suspended corridors on three sides. The only entrance is the semi-circular arched gate at the seventh axis of the Andrássy elevation. Above the ground floor, the first and second floor are corniced. Between the third and fourth floors, there is no cornice but a grand pilaster order connects them. Above the

12 Demolision plans in: BFL - 29244. hrsz. plans (VI-9-35) 18 September 1945. With the signature of György Kardos. fourth floor, there is an emphatic main cornice with an attic balustrade. The corner facade is stepped backwards, and the two last storeys are unified in a huge aedicula topped with statues. Here, above the corner façade, stood the original huge cupola; divided into an architectonic base and an ornamented church bell-shaped upper part with griffin statues. A neo-Renaissance weather vane completed the top of the dome.

\subsection{Andrássy Avenue facade}

The facade has twelve axes. Its rhythm is A-B-A-A-A-C-CC-A-A-A-B. The B-axes step forward fifteen centimetres as a small avon-corps. The windows on the ground floor are a series of arches with no parapets. The lowest section of the footing is red limestone; above it, there is a light grey limestone section with antique style border. The wall is covered with a strongly textured ashlar relief made of cement. The keystones of the arches are standing consoles with volutes, masks and fruit garlands. The keystone mask is a Hermes-head at the B-axes and lions on the others. Over the three middle $\mathrm{C}$-axes, there is a balcony on consoles above the gate on the first floor. Its arrangement is a loggia type, as in front of the Doric pilasters there are subsequent Doric columns. At B-axes, there are also balconies at the first, second and third floor. The connecting cornice turns onto the console's upper part and follows it around with a meandering motif and a lion's head to the front.

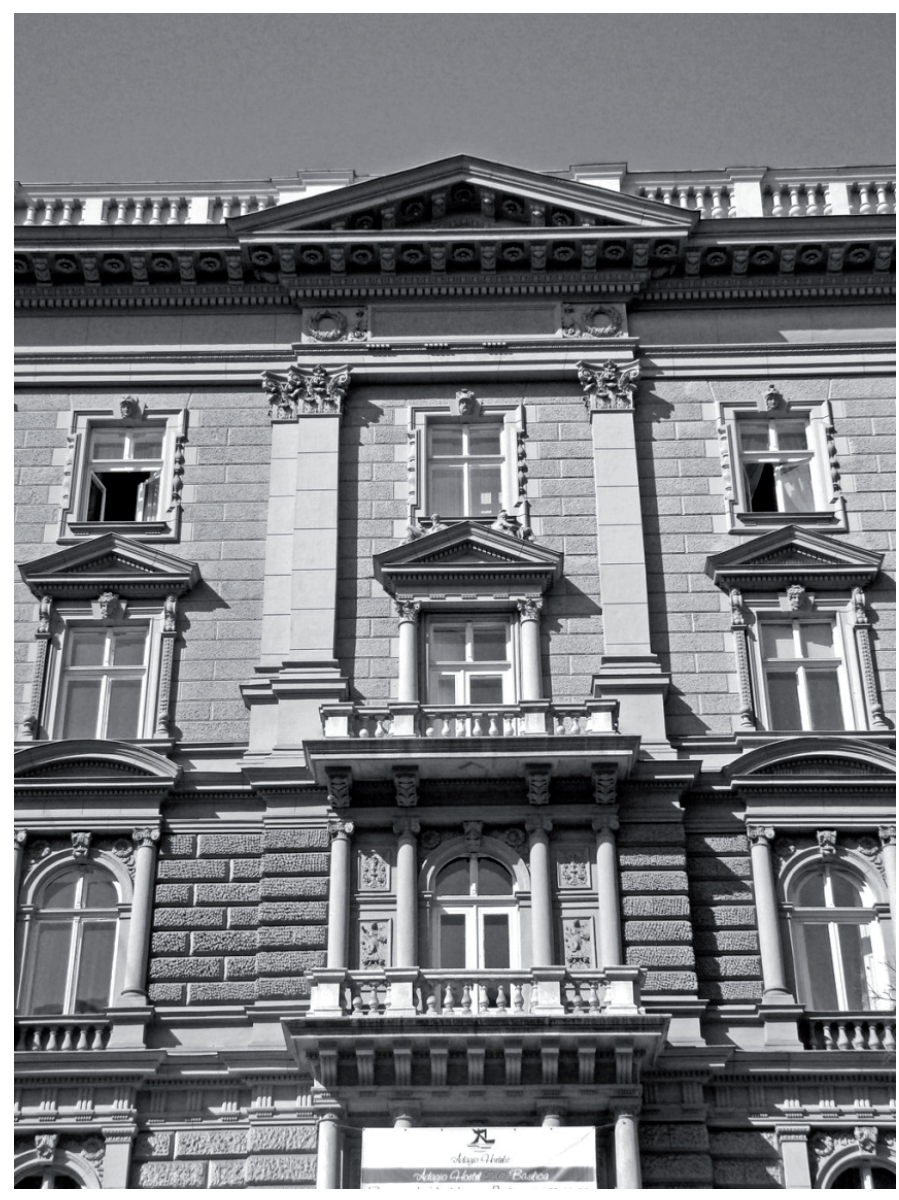

Fig. 5 Detail of the façade: B-axe (photo of the author 2014) 
The first floor is a part of the grand footing. It is set between two emphatic cornices. Doric pilasters border the windows, their axes emphasized with keystones. The outer edges of the archivolts are ornamented. The Doric pilasters are standing on a footing whose upper level is the same as the parapets. The upper cornice is Roman Doric style, with triglyphs and methopes; however, this structure differs in a mannerist way, because the taenia step forward in front of the triglyphs and the double-drops are hanging from that part. This emphasis still matches the facade, as if it emerged into space, as the Doric pilasters become columns and consoles from triglyphs (typical of late Renaissance); and, therefore, can support the balconies above. Between the double pilasters, we find 16th century (for example Palazzo Bevilacqua, Verona, Michele Sanmicheli, 1530) inspired reliefs.

The second-floor set is similar to the first floor. Between the plain footing and the three-part cornice, the wall is finished with an ashlar relief. The third floor contains a heavily denticular textured lower cornice. It creates an aedicula-like bordering to the windows similar to the keystones of the archivolts.

The third floor has no cornice above. At B-axes, footed Corinthian grand pilasters connect the two upper storeys. The wall's surface is almost plain, but it has a very soft ashlar, finish. The balcony windows have aediculas with three-quarter columns and Michelangelo-like positioned statues, as in Sagrestia Nuova, Florence (Michelangelo Buonarroti, 1527), on the tympanum. ${ }^{13}$

The windows on the fourth floor are lower. They have architrave bordering with half balusters and masked keystones on the top.

The main cornice is a classic Roman Corinthian cornice. There are ribbon-shaped reliefs in the freeze. At its top, there is a balustrade-attic with long, thin balusters. Undoubtedly, the reason for the thin shape is that they had to compensate the perspective distortion.

\subsection{Váci Road facade}

The architectural system is equivalent to that on Andrassy Avenue. Its rhythm is B-A-A-A-A-A-A-B-A. Of the two emphasized axes, the left one has no tympanum, although, the right one has a proper tympanum. The two B-axes have balconies the same as the Andrassy Avenue facade.

\subsection{Révay Street facade}

The architectural system is equivalent to that on Andrassy Avenue's. Its rhythm is B-A-A-A-A-A-B. Its shape is slightly less detailed than the main road facades as this faces to a backstreet.

13 These are displaying Roman gods. Neptune and Diana three times, Mars and Vulcanus twice, Mercury and Ceres also twice. (Déry, 2006:p.143)

\subsection{Corner facade}

This is a one-axis facade with five storeys. Its horizontal motifs are the same as the other facades. It has a strongly emerging middle avon-coups with a substantial aedicula on the third to fourth storeys. On the top of the aedicula, there are statues on the attic. In the centre of the ground floor, there is an arched portal, and on the first floor a closed balcony. The second-floor wall steps back slightly giving the space for the balcony. Above the third-floor balcony, there are statues of Neptune and Diana. On the two sides of the aedicula, there are two huge garland decorated vases. At the edges of the large tympanum, there are two sitting griffin statues, and in the middle, a statue of Mercury standing on a sphere. ${ }^{14}$ All three statues were gilded (BFU 1882:p.221).

\section{The cupola}

The huge corner cupola had a large irregular five-angled architectonic footing, which grew out from the palace's roof. On the corners of this base, there was a baroque style standing console that held the cornice running around the top of the footing. The cassettes between the corners include a diamond relief and tegula at the bottom edge. The lowest part of the cupola was a plain with palmette reliefs over the footing's corners. On that, there was a basement of three parts, heavily ornamented. Over the corners sat the three-meter high griffin bird statues with open wings. On the base, there was a row of ornamental acanthus decoration, with five small aedicula shaped roof windows. They had two balusters holding the tympanum, and a circular window. Above these was the slate roof covering, creating a rhombus-shaped pattern from different coloured elements. The top was completed with a metal lantern with six balusters and the spire of a weather vane, in German neorenaissance style, with the year of the building's completion and a dragon. Its urban landscape significance was obvious; it could be seen from the Buda Castle, as it emerged from the Pest skyline (Fortepan 30895), marking unmistakeably the starting point of Andrássy Avenue. The critics were mostly positive, but some felt the cupola was too sacral 'more like a church tower (VU 1884. no.7:p.109). Ultimately, Feszty's dome was more progressive than the previous examples, and it pointed towards the tendencies of the next century.

\section{Courtyard facades}

The courtyard includes a suspended corridor on three sides, held by triglyph patterned consoles; it has wrought iron banisters. The servant's staircase, with its unusually elegant entrance, is on the right-hand side of the yard. Above the upper floor, there is a strong main cornice, much simpler than the exterior one, but also in Roman Corinthian form.

14 Created by Gyula Szász (BFU 1882:p.221) 


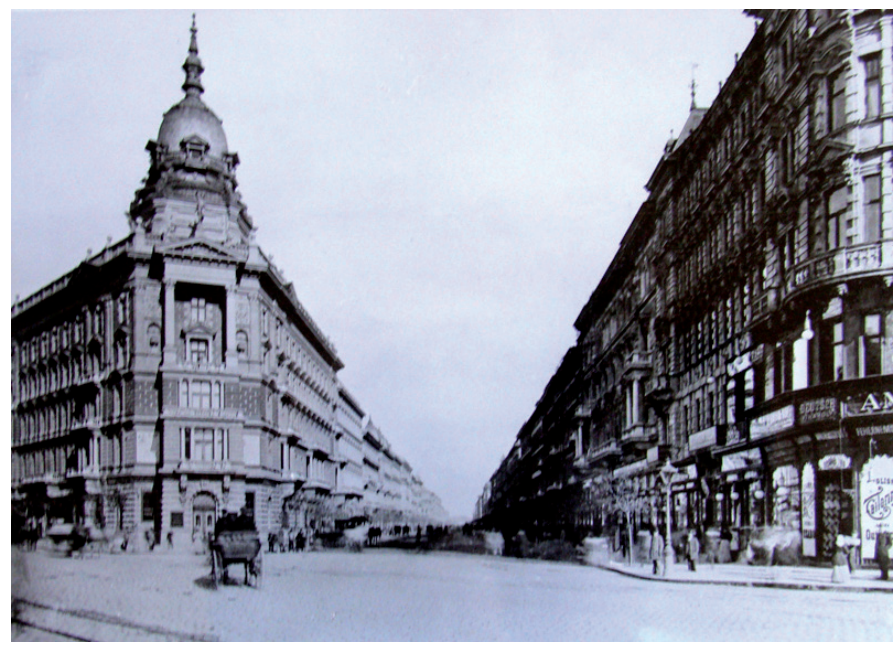

Fig. 6 The building in 1896 (BTM Photo archive, No. 2198033.)

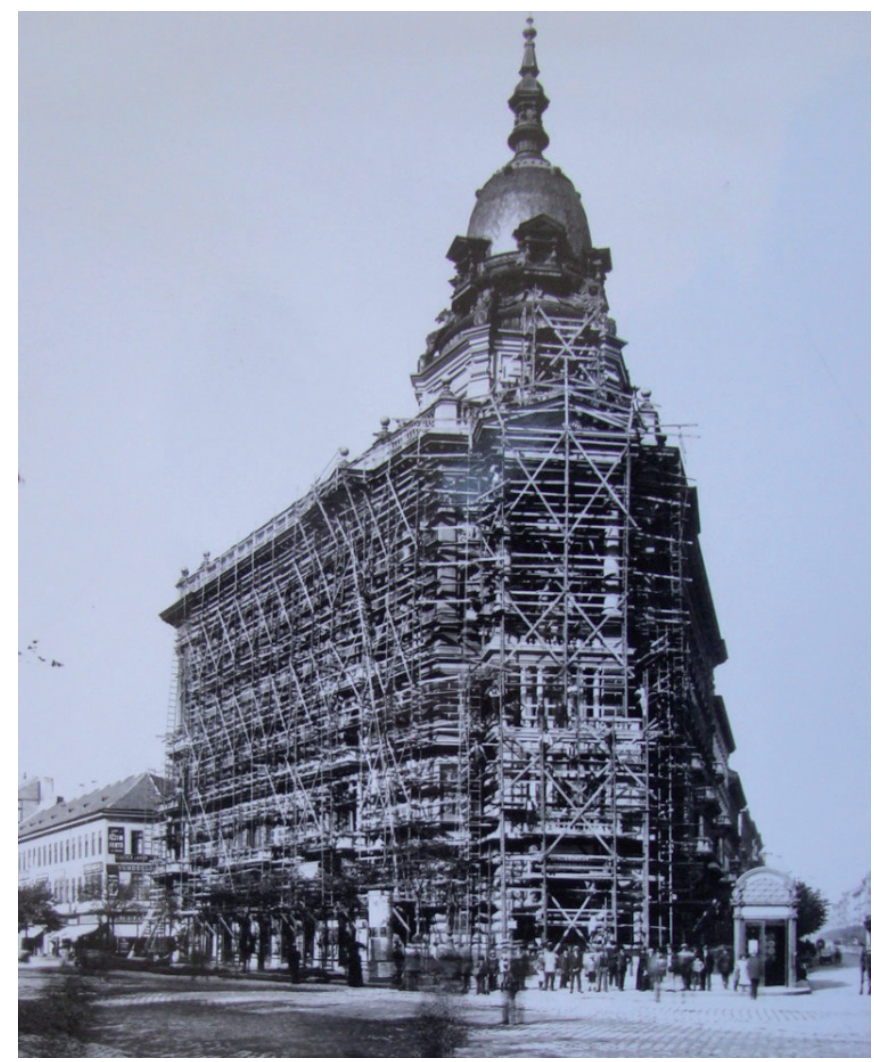

Fig. 7 Reconstruction works in 1900 (BTM Photo archive, No. 85.1739.)

There is also a small well in the yard. Its architectural frame consists of two dolphins with a semi-circular pool in front of it. It is made of limestone with a cast iron tap.

\section{Interiors}

Entering from the main gate, we arrive at the entrance corridor, which leads to the courtyard. At the end of it on the left, we find the entrance hall to the grand staircase. From the court, we can enter the service rooms of the ground floor shops. On the upper floors, the service rooms face to the courtyard, the prestigious enfilades can be found on the street fronts. The inner court wing consists of servant's rooms and their staircase.
The main gate is made of wrought iron. The entrance corridor has three sections, all of them covered by a cross vault. It has gilded stuccos and representative details. The vaults have laurel ornaments and baroque style shields with rosettes on the top. Along the two walls stand the Ionic marble columns. Their capitals are made of white marble, the body from brown and the footing from black Salzburg marble. The pavement was originally wood. From the middle of the vaults, there are hanging lamps, all of wrought iron. From the third vault, we can enter the court, or turn left to the entrance hall in which there is a Venus statue in front of the arrival. From here, we continue to the main staircase. The 1st banister is from wrought iron; the Corinthian columns are of cast iron made by the 'Ganz' company; some parts and the iron beams were made by the Schlick factory (BFU 1882:p.221) On the Andrássy wing, there are sandstone balustrades and Ionic columns on each storey. The ceiling of the stairway has gilded laurel-patterned stuccos forming an octagonal motif.

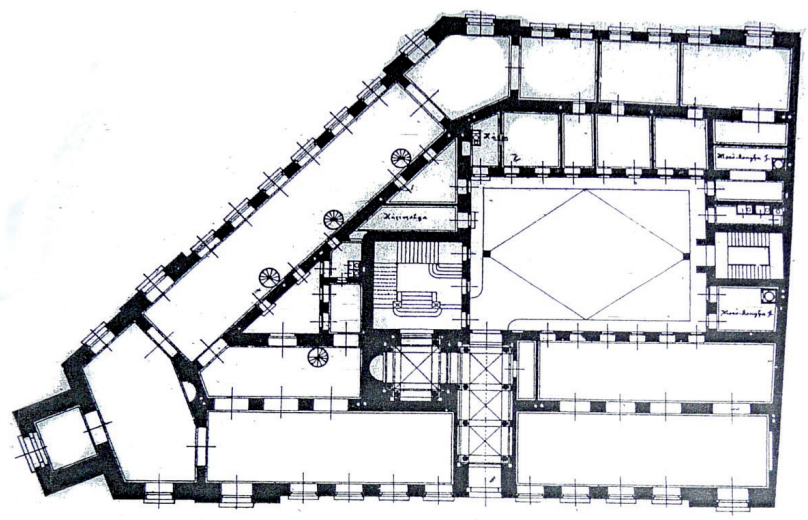

Fig. 8 Ground floor plan, 1882 (Bauzeitung für Ungarn 1882:p.225)

\subsection{Apartments}

The layout of the flats was very modern at the time. Each possessed an own bathroom, and they were equipped with all the modern technical features: steam heating, gas lighting, telegraph, modern toilets. They all composed of two sections; in the inner section were the bathrooms, kitchen, etc., in the street sections were the large elegant rooms. A flat had from three to five large rooms. These had stucco ceilings, silk wallpapers, marble fireplaces and richly patterned parquets. The doors were painted with neo-renaissance ornamental pattern; some of them have survived and can be seen on the second-floor flats (painter: A. Bergmann). Originally, there were nineteen flats in the palace, with no court-wing flats due to the demanding design and the characteristics of the site (BFU 1882:p.221).

\section{Architectural shaping}

The overall picture of the palace's architecture reflects a sort of academic elegance. The dynamism of the tiny details gives a late Historicism favour to the facade. The fine but also 


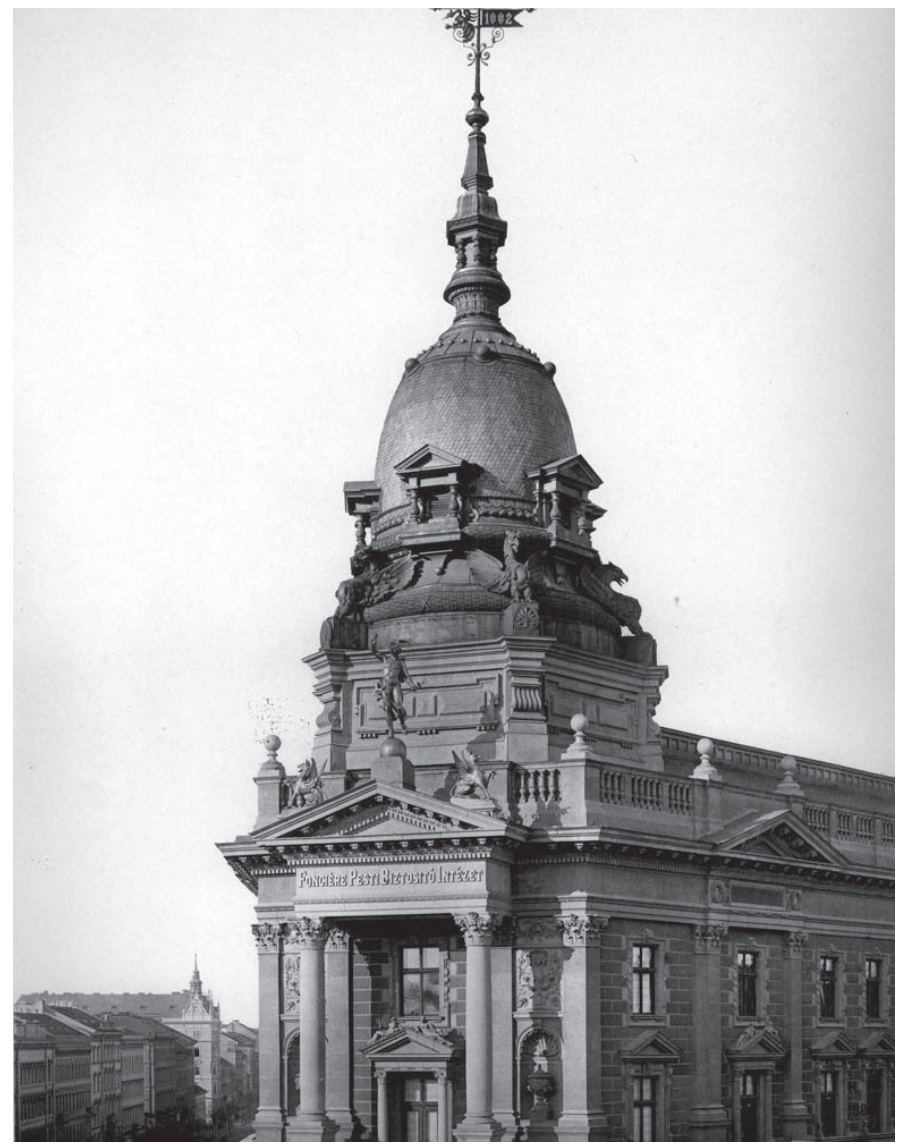

Fig. 9 Photo of the cupola by Hermann Rückwardt, 1889 (FSZEK Budapest collection, No. 000719.)

progressive differences from the classical set methods add to the palace's unique atmosphere. For example, third-floor window borders appear classical from far away, but the details observed from close to are very innovative. The location of the building demarcates the locations of the significant statues, like the gilded Mercury and the griffin on the façade, common of the age. It was a challenge to the designer that he had to create a residential building that looked like a representative public building. He was not able to include the representative interior spaces, but simple rooms, consequently, the external emphasis did not correlate with the interior structure. Feszty solved this problem by not creating disharmony between the inside and the outside, yet still produced a prestigious external appearance. First, he had to continue the line of the Andrássy Avenue houses, and also follow the Bajzsy Zsilinszky Road axis. The corner façade on the meeting point of these two main facades became the most emphatic element of the exterior. This facade has the most representative shape, the classical motifs, existing on other facades, appear here in a most sculptural way. Doric, Ionic and Corinthian columns above each other are following the traditional coliseum motif. The five-storey motif steps more into space than the side facades as the grand pilasters become columns, with a real portico. This can also be observed on the plaster model, although, on the model, all the B-axes had tympanums with obelisks. Above the corner, Feszty designed a huge cupola. On the model, it was significantly

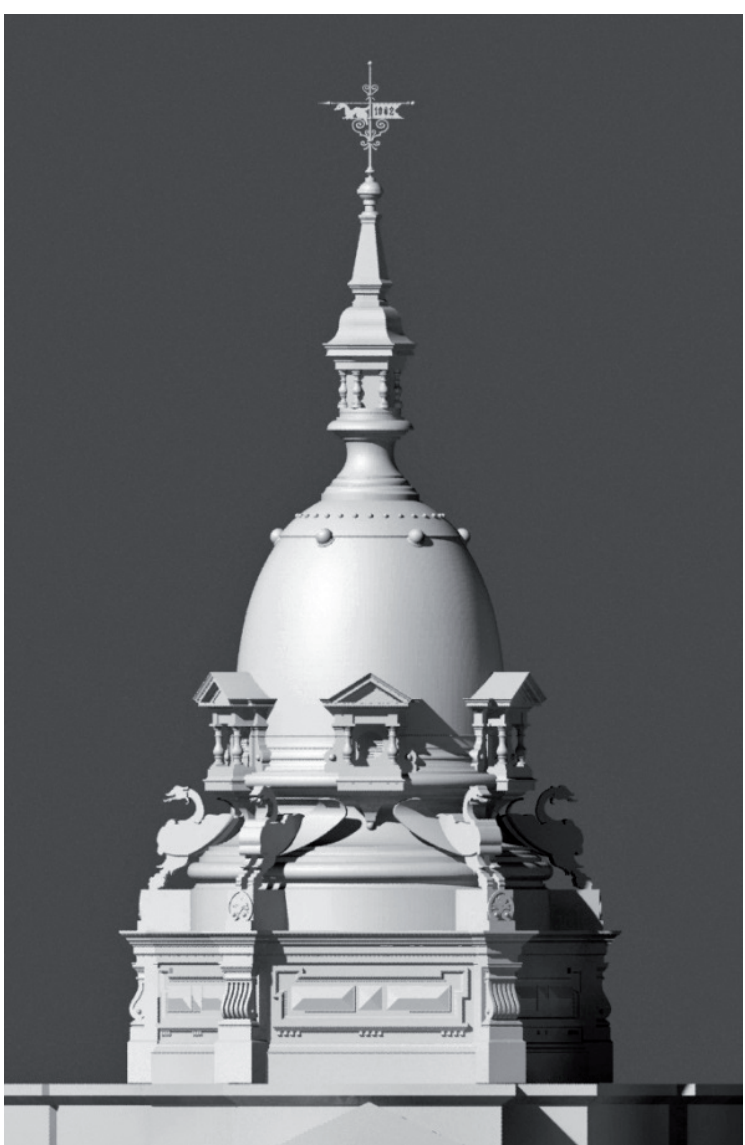

Fig. 10 Study plan of the reconstruction of the cupola, rendering (the author, 2013)

lower; Feszty modified the cupola plans later. It became higher, more emphatic, although the attic of the side facades changed to be simpler, less emphatic. The obelisks changed to spheres, and all tympanums were gone except the two next to the corner facade. It harmed the inner symmetry of the side facades and put the emphasis on the domed corner. With this, Feszty provided a virtuoso solution to the starting point of Andrássy Avenue using the achievements of Late Historicism.

\section{Present state and issues of reconstruction}

The building and its neighbourhood fortunately survived the Second World War and other vicissitudes. Its location is still important, perhaps more so following the demolition of some relatively insignificant buildings and their replacement by Finta's new office building, built in 1989. Its facades are in an excellent state thanks to recent and frequent restorations. The sculpture and decoration are intact, emphasising even more conspicuously the missing cupola. It is perhaps an understatement that its reconstruction is highly desirable. With this, the architectural values of the building would be restored, and its former role in the urban landscape of Budapest would be reinstated. As the original construction was well founded, the reconstruction is even more necessary. Remains of the dome structure can still be found in the attic, its form could be redesigned using the original plans and an exceptionally good quality photo. With both these resources, every detail could be subsequently restored. 
Utilising these documents and with the descriptions from contemporary articles, the paper's author has produced a study plan for the reconstruction, which can be seen here.

Its reconstruction would add an architectural gem to the city landscape of Budapest, and fulfil a 19th-century architect's life's work.

\section{References}

Borsa, M., Tolnay, P. (1984) Az ismeretlen operaház. Budapest: Műszaki könyvkiadó. (in Hungarian)

Déry, A. (2006) Terézváros - Erzsébetváros: VI.-VII: kerület. Budapest: Terc kiadó. (in Hungarian)

Hajós, Gy. (2001) Heroes ’square. Budapest: Fővárosi Önkormányzat.

Kemény, M. (1991) Stílusválság vagy legitimitási válság?. 2000. pp. 57-60. (in Hungarian)

Pereházy, K. (2000) A Sándor utcai Képviselőház. In: Lengyel, J. Az Ország háza-Buda-pesti országháza. (in Hungarian)

Preisich, G. (2004) The building history of Budapest. Budapest: Terc Kiadó.

Szénássy, Á. (1993) The life and work of Adolf Feszty. Budapest: Írók Alapítványa Kiadó

Vadas, F. (2007) Scientific documentation of the Fonciére palace, 2 Andrássy avenue. Budapest: Hild-Ybl Foundation.

Winkler, G. (1993) Urban planning in the historicism. In: Müvészettörténeti tanulmányok. pp. 31-48.

Ybl, E. (1956) Ybl Miklós. Budapest: Képzőművészeti Alap Kiadóvállalata. (in Hungarian)

BFU: Bauzeitung für Ungarn, weekly journal, 1876-1896., Eduard Korhnoffer, Budapest

Épip: Építési Ipar, weekly journal, 1877-1932., Városi Mérnökök Országos Szövetésge,Budapest

fortepan: Fortepan, website of archive photographs, http://www.fortepan.hu/

MMÉEg: MMÉE gazette, Official weekly journal of the Hungarian Association of Engineers and Architects, 1867-1944, Magyar Mérnök- és Építész Egylet, Budapest, http://epa.oszk.hu/01400/01451\#/

VU: Vasárnapi Ujság. weekly journal, 1854-1921, Franklin Society, Budapest, http://epa.oszk.hu/00000/00030\#/ 